\title{
On the Popular Image of the Lawyer: Reflections in a Dark Glass
}

\author{
Robert C. Post $\dagger$
}

The most striking aspect of the image of the lawyer in popular culture is the intense hostility with which it is imvested. Lawyers, to be sure, inay have inore than their fair share of cominon inoral shortcomings. But they do not as individuals seem so very different from the rest of the population as to justify the special level of animosity that the profession seems to arouse in the general public. One thinks, for example, of the present genre of what has coine to be called "lawyer jokes." For instance:

Question: What is the difference between a dead lawyer in the road and a dead skunk?

Answer: There are skid narks by the skunk.

Or:

Question: Why did the research scientist substitute lawyers for rats in his laboratory experiments?

Answer: Lawyers breed more rapidly, scientists became less attached to them, and there are some things that rats just won't do.

Lawyer bashing is of course nothing new. The genre goes back a long way. St. Luke says in the New Testament: "Woe unto you also, ye lawyers! for ye lade inen with burdens grievous to be borne ...."1 Every lawyer or legal academic carries as a particularly heavy part of her cultural traming the usual and vicious swipes at lawyers, froin Shakespeare's "let's kill all the lawyers,"2 to Sir Thomas More's exclusion of lawyers froin his Utopia because they are "a sort of people, whose profession it is to disguise matters."3 The nineteenth-century readers and spellers of American schoolchildren often contamed a game called "the Colomists,"

$\dagger$ Acting Professor of Law, Boalt Hall School of Law, University of California, Berkeley. A.B. 1969, Harvard College; J.D. 1977, Yale Law School; Ph.D. 1980, Harvard University.

1. Luke 11:46.

2. W. SHAKESPEARE, HENRY VI, pt. II, act 4, sc. 2, 1.68. Because the character who actually makes this remark is so very unsavory, it is by no means clear that Shakespeare meant the line to carry the opprobrious meaning for which it is cited in popular literature.

3. T. MORE, UTOPIA 128 (G. Burnet trans. 1821) (1516). For pure venomous hatred, however, it is hard to match Coleridge's lesser known lines:

He saw a Lawyer killing a Viper

On a dunghill hard by his own stable;

And the Devil smiled, for it put him in mind

Of Cain and his brother Abel.

S.T. Coleridge, The Devil's Thoughts, in Complete Poetical Works 320 (1912). 
which ranked various occupations. Farming, of course, always stood at the head of the hist. The attitude toward lawyers was contained in the following quatrain:

To fit up a village with tackle for tillage

Jack Carter he took to the saw.

To pluck and to pillage, the same little village

Tim Gordon he took to the law. ${ }^{4}$

The question, then, is what accounts for this pervasive and intense hostility. A recent poll conducted by The National Law Journal asked people what most closely represented their view of the inost negative aspect of lawyers. By far the largest proportion, $32 \%$, disapproved of lawyers because "[t]hey are too interested in money." While that may well (for all I know) be a correct characterization of lawyers, it is hardly a umque one: Avarice does not seem to distinguish lawyers from businessmen or architects or doctors. But the second and third reasons for thinking ill of lawyers were different. They were that lawyers "manipulate the legal system without any concern for right or wrong" (22\%), and that they "file too many unnecessary lawsuits" (20\%). ${ }^{6}$

These are reasons to dislike lawyers that are specific to the legal profession. What is fascinating about these reasons, however, is that when The National Law Journal asked the pubhic what were the most positive aspects of lawyers, far and away the most popular responses were that their "first priority is to their chents" (38\%), and that they "know how to cut through bureaucratic red tape" (31\%)." In other words, lawyers are applauded for following their chents' wishes and bending the rules to satisfy those wishes; and they are at the very saine time condemned for using the legal system to satisfy their clients' desires by bringing lawsuits at their chents' behest and using the legal systein to get what their chents want, rather than to uphold the right and denounce the wrong.

Lawyers, it seems, can't win for trying. They are simultaneously praised and blained for the very same actions. If The National Law Journal's poll is to be credited, popular attitudes toward lawyers are profoundly contradictory. ${ }^{8}$ Often, however, such contradictions are fault lines leading right to the heart of a culture's vision.

4. Quoted in R.M. Elson, Guardians of TRAdition: AMERICAN Schoolbooks of THE NINETEENTH CENTURY 26 (1964).

5. What America Really Thinks About Lawyers, NAT'L L.J., Aug. 18, 1986, at S.3.

6. Id.

7. Id.

8. These contradictory attitudes also surfaced in a 1981 survey conducted by the American Bar Foundation. The ABA found that although members of the public scorn the image of the "shyster," they also "indicated that when they do scek a lawyer, they may want one who most fits the shyster image." Podgers, Public: 'Shyster' OK - If He's on Your Side, 67 A.B.A. J. 695 (1981). 
Consider, for example, the fact that lawyers are praised for cutting through bureaucratic red tape. One can find that same image repeated in popular culture with an exactly opposite emotional spin. In the American writer Winston Churchill's popular 1914 novel A Far Country, for example, the hero is a corporation lawyer who gradually acquires a social and moral conscience. Early in his career he views the function of the corporate lawyer to be helping business "get 'round" the laws that "darned fools in the legislatures" enact. ${ }^{9}$ For Churchill, this function of cutting through red tape was evidence of lawlessness. A similar image of the lawyer as lawless is in fact quite common in popular culture. It was most pithily stated by Benjamin Franklin's Poor Richard: "Necessity has no Law; I know some Attorneys of the name."10 Two and a half centuries earlier King Louis XII of France is reported to have said, "Lawyers use the law as shoemakers use leather; rubbing it, pressing it, and stretching it with their teeth, all to the end of making it fit their purposes."11

What exactly does it mean to say that lawyers are lawless? One hiteral meaning is illustrated by that marvelous screwball comedy, The Talk of the Town, in which Ronald Colman plays an emment and hightoned law school professor who is about to be nominated to the Supreme Court. ${ }^{12}$ Colman is bloodless; he is a man of lofty ideals and strong intellect, but he has no passion or practicality. His hands are lily white. $\mathrm{He}$ is spending the summer $\mathrm{m}$ a small town in Western Massachusetts waitmg for his nommation to be presented to the Senate. He takes in a local woman, Jean Arthur, as his housekeeper.

The town's mdustrialist has just burned down his mill; it has become unprofitable and he wants the insurance proceeds. He blames the fire on the town anarchist, Cary Grant. Grant seeks the help of his old friend Jean Arthur, who hides him in Colman's house. The usual Hollywood coinplexities ensue: Grant and Colman spar with each other about the meaning of the law; both fall in love with Arthur (as who wouldn't), etc. But the essential point of the movie is Colman's realization that the law must be practiced as well as preached, that it requires action as well as thought. Colman acts on his new insight by driving to Boston and kidnapping the real arsonist. At the movie's climax Colman enters a courtroom where a mob is about to lynch Grant, and, dragging the arsomist by the scruff of his neck and shooting his pistol into the air, he quiets the mob by telling them that the law is their most precious possession and that they must always respect its processes.

9. W. Churchill, A. FAR Country 139 (1914).

10. B. Frankin, Poor Richard's Almanacks 21 (1964) (1734).

11. Kupferberg, An Insulting Look at Lawyers Through the Ages, JuRIS Doctor, Oct./Nov. 1978 , at 62.

12. The Talk of the Town (Columbia Pictures 1942). 
It is a wonderful moment. The man who has just forcibly kidnapped the criminal is lecturing the crowd on the virtue of the law. The paradox is not accidental, for the very thrust of the film is that Colman's willingness to break the law qualifies him for the Supreme Court. Sometimes, in other words, the lawyer must be lawless in order to uphold the law. Put that way, of course, we can begin to recognize a classic American theme.

You can see the same theme associated with lawyers in John Ford's western The Man Who Shot Liberty Valence, in which Jimmy Stewart plays an awkward, peaceable young eastern lawyer, come to the rugged west to make his fortune. ${ }^{13} \mathrm{He}$ is tormented to distraction, as is the whole town, by the vicious outlaw Liberty Valence (played by Lee Marvin). Pushed beyond endurance, Stewart, who barely knows how to handle a pistol, challenges Marvin to a gunfight, and when the town thinks that he has shot Marvin to death, they are overjoyed and elect him to public office. He eventually becomes a Umited States Senator, and the triumph of his career is associated with the transition from territory to statehood, the emergence of commerce and industry, and the coming of law, order, and civilization.

We as an audience know, however, that Stewart did not really kill Liberty Valence; that in fact he would have been slaughtered like a lamb had it not been for the timely and secret intervention of John Wayne, who had killed Liberty Valence at the crucial moment. Wayne is the loner, the man associated with the old West, for whom Stewart's civilization has no place. In Liberty Valence, in other words, as in The Talk of the Town, the lawyer's law and civitization, which is our own culture, rests on violence. The law is founded on force and is parasitic on lawlessness, and that has been a major theme of American culture at least since Jaines Femimore Cooper's Leatherstocking Tales.

But this is not what is meant when lawyers are attacked in popular culture for being lawless. Stewart and Colman are heroes; they are not the objects of censure. When lawyers as a profession are negatively associated with lawlessness, the thrust of the accusation is something different. It is not that all lawyers are actual criminals, literally breaking the law, it is rather that the concept of "law" itself has assumed a double meaning. Law is on the one hand the positive enactments of the state. Law in this sense is technical, ambiguous, and complex. It can almost always be circumvented, as $\mathrm{m}$ the old adage, " $\mathrm{A}$ coach and four may be driven through any Act of Parhament." 14 Lawyers obey this kind of law, as was recently said of the White House and its secret aid to Iran and the

13. The Man Who Shot Liberty Valence (Paramount Pictures 1962).

14. The Facts on File Dictionary of Proverbs 138 (R. Fergusson ed. 1983) [hereinafter Dictionary of Proverbs]. 
contras, by ascertaining its "legal limits" and escaping through its "loopholes."15 But by dealing in this strict if dubious legality, lawyers stand accused of breaking a different kind of law, the law which is associated with justice and with our values as a community. This is the kind of law that Herachitus has in mind when he says in his Fragments that "[t]he people inust fight for their law as for their city wall."16 It is the kind of law that Stewart and Coman were in fact required to fight to establish.

Popular culture is filled with images of the contradiction between these two kinds of law. Consider, for example, the old proverb: "Much law, but hittle justice."17 Or consider this sixteenth-century song about the wholesome life of shepherds:

For Lawiers and their pleading

The[y] 'steeme it not a straw,

They think that honest meaning

Is of it selfe a law,

Where conscience judgeth plainely,

They spend no mony vainely. ${ }^{18}$

Here the law of lawyers is technical and artificial, and severed from the wholesome law spontaneously available to every honest participant in community life. Sir Thomas More's rejection of lawyers in his Utopia, of course, rests on exactly the same opposition. ${ }^{19}$ If you think this opposi-

15. Engelberg, Contra Aid: Loose Law?, N.Y. Times, Jan. 15, 1987, at A-12; see also Johnson, The Arrogance of Power-Again, Wash. Post, Nov. 26, 1986, at A-2.

16. C. KaHN, The ART AND Thought of Heraclitus: AN Edition of THE FRAGMENTS WITH TRANSLATION AND COMMENTARY 59 (1979). It is also the kind of law that is often referenced in the self-congratulatory rhetoric of the bar. In his 1845 address to the Harvard Law School, for example, Rufus Choate argued that lawyers "perform certain grand and difficult and indispensable duties of patriotism" because they serve a law that

is not the transient and arbitrary creation of the inajor will, nor of any will. It is not the offspring of will at all. It is the absolute justice of the State, enlightened by the perfect reason of the State. That is law. Enlightened justice assisting the social nature to perfect itself by the social life.

R. CHOATE, The Position and Functions of the American Bar, as an Element of Conservatism in the State: An Address Delivered Before the Law School in Cambridge, July 3, 1845, in ADDRESSES AND ORATIONS OF RuFus ChoATE 135, 156 (4th ed. 1883).

17. Dictionary of Proverbs, supra note 14, at 138.

18. What Pleasure Have Great Princes in W. Byrd, Psalmes, Sonets \& Songs of SAdNes and Pietie, Made into Musicke of Five Parts xix (1588).

19. They have but few laws, and such is their constitution, that they nced not inany. They do very much condemn other nations, whose laws, together with the commentaries on them, swell up to so many volumes; for they think it is an unreasonable thing to oblige men to obey a body of laws, that are both of such a bulk, and so dark, that they cannot be read or understood by every one of the subjects.

They liave no lawyers among them, for they consider them a sort of people, whose profession it is to disguise inatters, as well as to wrest laws; and therefore they think it is much better that every inan should plead his own cause, and trust it to the judge, as well as in other places the client does it to a counsellor. By this means they both cut off inany delays, and find out truth more certainly: for after the parties lave laid open the inerits of their cause, without those artifices which lawyers are apt to suggest, the judge examines the whole matter, and supports the simphicity of such well-meaning persons, whom otherwise 
tion is merely a Renaissance obsession, consider David Graham Phillips's popular 1909 novel, The Fashionable Adventures of Joshua Craig.

The liero of the novel is Josh Craig, a rugged western lawyer who comes to Washington to serve as Deputy Attorney General. The first case lie is assigned to argue before the Umited States Supreme Court is a certain loser, but against all odds Craig manages to win a victory for the government. Phillips's description of tlie arguinent is extraordinarily ricli, but let me quote only part of one paragrapli:

Never was there a better court manner; the Justices, who had been anticipating an opportumity to demonstrate, at his expense, the exceeding dignity of the Supreme Court, could only admire and approve. As for his speech, it was a straightway argument; not a superfluous or a sophomoric word, not an attempt at rhetoric. ... There is the logic that is potent but answerable; there is the logic that is unanswerable, that gives no opportumity to any sane mind, however prejudiced by association with dispensers of hospitality, of vintage wimes and dollar cigars, however enamored of fog-fighting and hair-splitting, to refuse the unqualified assent of conviction absolute. That was the kind of argument Josh Craig made. And the faces of the opposing lawyers, the questions the Justices asked him plainly showed that he had won. ${ }^{20}$

The passage rests on tle opposition between logic that is answerable, and logic tliat is unanswerable; between reasons that are hair splitting, and reason tliat is absolute; between values that are partial, associated witli a particular cigar-smoking, wine-drinking class, and values that are universal, associated with tlie community as a whole. Lawyers, Phillips implies, serve their higliest function wlien they speak for tliat larger community. Then tliey serve tlie true law. ${ }^{21}$

crafty men would be sure to run down: and thus they avoid those evils, which appear very remarkably among all those nations that labour under a vast load of laws. Every one of them is skilled in their law, for as it is a very short study, so the plainest meaning of which words are capable, is always the sense of their laws.

T. MORE, supra note 3, at 128-29.

20. D.G. Phillips, The Fashionable Adventures of Joshua Craig 75 (1909).

21. Like Phillips, the established bar has traditionally attempted to rationalize its function in terms of the umiversal value of justice. Consider, for example, Joseph Choate's 1905 address to the bench and bar of England:

I started in life with a belief that our profession in its highest walks afforded the inost noble employment in which any man could engage, and I ain of the same opinion still. ... . To be a priest, and possibly a high priest, in the temple of justice, to serve at her altar and aid in her administration, to maintain and defend those inalienable rights of life, liberty, and property upon which the safety of society depends, to succor the oppressed and to defend the innocent, to mamtain constitutional rights against all violations, . . . to rescue the scapegoat and restore him to his proper place in the world-all this seemed to me to furnish a field worthy of any man's aunbition.

J. CHOATE, Farewell to the English Bar: Speech at a Dinner Given in His Honor by the Bench and Bar of England, at Lincoln's Inn, London, April 14, 1905, in ARGUMENTS AND ADDRESSES OF JOSEPH HODGES CHOATE 1109 (F. Hicks ed. 1926). Perhaps the most widely accessible contemporary image of a lawyer serving justice may be found in the career of Perry Mason, who over the years managed never to represent a guilty client. See Chase, Lawyers and Popular Culture: $A$ Review of 
But this is to place quite a burden on lawyers. ${ }^{22}$ For one thing, it assumes that such a larger community exists, that it can be perceived in a way that transcends particular, and therefore partial perspectives, and that the imperatives of that community can be communicated with an unanswerable logic. In inost actual hitigation, of course, lawyers speak for the particular perspective of their client, and atteinpt to argue that that perspective is the better way to perceive tlie values at stake in a given controversy. Their arguments are almost always answerable. And in tliese respects they betray their duty to the more fundamental law.

In popular culture the symbol of this betrayal is the lawyer's fee. The lawyer is seen as abandoning his duty as a citizen and advocating the partial perspective of his chent for the sake of his large wages. ${ }^{23}$ But these are the wages of corruption, for they bind the lawyer to attack the cominumity's most precious possession, its fundamental law. John Dryden said it well:

Asebia: We never valu'd right and wrong

But as they serv'd our Cause.

Zelota: Our Business was to please the Throng

And court their wild applause.

Asebia: For this we brib'd the Lawyer's Tongue

And then destroy'd the laws. ${ }^{24}$

In point of plain fact, however, the lawyer's betrayal is most often not a matter of corruption or ill will. It coines instead froin tlie unpleasant fact that we do not live in a society ordered by a spontaneous, colierent system of values, but instead in a wildly pluralistic culture, in whicl individuals constantly struggle to achieve recognition for the legitimacy of tlieir private perspectives. We have organized our legal system so tliat lawyers speak for the specific and particular sides of this struggle. Most commonly, wlien a lawyer argues for one interpretation of a law rather

Mass Media Portrayals of American Attorneys, 1986 AM. B. Found. REs. J. 281, 283. For an extended discussion of the analogous image of the lawyer as the "expounder and guardian of republican virtue" during the early years of the Republic, see R. FERGUSON, LAW AND LETTERS IN AMERICAN CULTURE 26, 11-33 (1984).

22. It is a burden, however, that lawyers have cheerfully accepted. See supra notes 16,21 .

23. Consider, for example, Hilary Vane's confession in Winston Churchill's 1908 novel Mr. Crewe's Career. Vane is a powerful railroad attorney who has come to see the hight:

I deceived myself for a long time by beheving that I earned my hiving as the attorney for the Northeastern Railroads. I've drawn up some pretty good papers for them, and I've won some pretty difficult suits. I'm not proud of 'em all, but let that go. Do you know what I am? citizen.

I'm their paid political tool . . . . I've sold them my brain, and my right of opimion as a

W. Churchill, Mr. Crewe's Career 443 (1908).

24. J. DRYDEN, Albion AND Albanius: AN Opera 23 (London 1691). The opera is an allegory about the political fate of Albion in which Asebia represents "Atheism, or Ungodliness," and Zelota stands for "Feigu'd Zeal." Id. at 2. 
than another, she is arguing for one ordering of values, rather than another.

Value is thus pitted against value, and lawyers' hitigation is as a result transformed, to appropriate a phrase froin Hugh Brackenridge's early American novel Modern Chivalry, into "an image of war."25 Or, in the language of George Eliot's The Mill on the Floss, "a sort of cockfight, in which it [is] the business of injured honesty to get a gaine bird with the best pluck and the strongest spurs."26 This takes us quite far from the image of a spontaneous law, available to all, that tangibly encircles us and gives shape and meaning to our culture, like a "city wall." The image now is that of internecine war, in which lawyers are the shock troops, threatening to tear down what we have spontaneously in common.

And this returns us to the National Law Journal's finding that lawyers are especially disliked because they inanipulate the legal system in the interests of their particular chents, without regard to the coinmon, universal values of right and wrong. But recall also that lawyers are praised because their first priority is to the private perspective of their chents. Lawyers, in other words, bestride the following cultural contradiction: we both want and in soine respects have a universal, coininon culture, and we simultaneously want that culture to be malleable and responsive to the particular and often incompatible interests of individual groups and citizens. We expect lawyers to fulfill both desires, and so they are a constant irritating reminder that we are neither a peaceable kingdom of harmony and order, nor a land of undiluted individual autonomy, but somewhere disorientingly in between. Lawyers, in the very exercise of their profession, are the necessary bearers of that bleak winter's tale, and we hate them for it.

We hate them, that is, because they are our own dark reflection. We use lawyers both to express our longing for a commion good, and to express our distaste for collective discipline. When we recognize that the ambivalence is our own, and that the lawyer is merely our agent, we use the insight as yet another club with which to beat the profession. For then we dismiss the lawyer as a mere "hired gun," or "paid . . . tool,"27 or, worse yet, as an inveterate har. ${ }^{28}$ The charge of insincerity strikes a particularly tender nerve in the inodern sensibility, because as a culture we are in a state of such uncertainty concerning the nreaning of authenticity.

25. H. BrackenRIDGe, MODERN ChivalRy 365 (1937) (1815).

26. G. Eliot, The MiLl ON THE Floss 165 (London 1860).

27. W. CHURCHILL, supra note 23 , at 443.

28. As in the contemporary lawyer joke that asks: "How do you know when a lawyer is lying?" The answer is: "His lips are moving." 
We owe especially to the sociologist Erving Goffman the insight that the self in inodern society can be understood not as soinething of substance that actually exists, but rather as a series of performances. The character attributed by others to an individual is the result of these performances. Goffman tells us:

In our society the character one performs and one's self are somewhat equated, and this self-as-character is usually seen as something housed within the body of its possessor .... I I suggest that this view is . . a bad analysis of the presentation. In this [book] the performed self was seen as some kind of image, usually creditable, which the individual on stage and in character effectively atteinpts to induce others to hold in regard to him. While this image is entertained concerning the individual, so that a self is imputed to him, this self does not derive from its possessor, but from the whole scene of his action, being generated by that attribute of local events which renders them interpretable by witnesses. ${ }^{29}$

It is of immense importance for us as a society, however, to deny this insight. We get queasy when we view the personality of others to be constituted merely by a series of staged performances. ${ }^{30}$ Sartre inakes a similar point in his famous analysis in Being and Nothingness:
A grocer who dreams is offensive to the buyer, because such a grocer is not wholly a grocer. Society demands that he limit himself to his func- tion as a grocer, just as the soldier at attention makes himself into a sol- dier-thing with a direct regard which does not see at all .... There are indeed many precautions to imprison a man in what he is, as if we lived in perpetual fear that he imight escape from it, that he imight break away and suddenly elude his condition. ${ }^{31}$

This perpetual fear of the self escaping its concrete and given substance is in some measure behind the centuries of abuse and loathing that the premodern era poured onto actors, ${ }^{32}$ for actors are the living embodiment of the performing, protean self. Jean-Jacques Rousseau, for example, thought actors "dishonorable" because the talent of the actor hes in "the art of counterfeiting himself, of putting on another character than his own, of appearing different than he is, ... of forgetting his own place

29. E. Goffman, The Presentation of Self in Everyday Life 252 (1959).

30. For a criticisin of "the 'dramaturgic approach' to social experience," see Messinger, Life as Theater: Some Notes on the Dramaturgic Approach to Social Reality, 25 SociomETRY 98 (1962).

31. J. SARTRE, BEING AND NothingNess 59 (H. Barnes trans. 1956).

32. "[I]n every country their profession is one that dishonors, ... [t]hose who exercise it, excommunicated or not, are everywhere despised . . . ." J. RousSEAU, Politics AND THE ARTS: LETTER TO M. D'AlemBert ON THE THEATRE 76 (A. Bloom trans. 1960) (1758). For a suminary of traditional excoriations of the acting profession, see W. PrynNe, Histrio-Mastix. The Player's Scourge OR, ACtors Tragaedie 841-48 (London 1633). For Prynne, the "very profession of a Stage-player, together with the acting of Playes and enterludes, either in publike theatres or private houses; is infamous, Scandalous, and no wayes lawfull unto Christians." Id. at 831. 
by dint of taking another's."33 Rousseau contrasted the actor to the orator:

When the orator appears in public, it is to speak and not to sliow himself off; he represents only himself; lie fills only his own role, speaks only in his own name, says, or ouglit to say, only what he thinks; tlie inan and the role being the same, he is in his place; he is in the situation of any citizen who fulfils tlie functions of his estate. But an actor on the stage, displaying other sentiments than his own, saying only what lie is made to say, often representing a chimerical bemg, annihilates himself, as it were, and is lost in his hero. ${ }^{34}$

Actors, however, he directly: we all know that Olivier is only pretending to be King Lear, and that it is just a performance. But consider, in this liglit, the trial lawyer inaking a summary to the jury. In that case we know both (1) that the lawyer must be representing the interests of his chent, so that his speech does not smcerely represent his "personal" views; and (2) that if the lawyer distinguishes between his personal views and those of his chent, his chent will suffer, so that the lawyer can perform his job only if he "appears" to be and im fact convinces us that he is sincere. Unlike the actor, then, the lawyer's job requires that he totally conceal his performance. And he must do this about issues of public importance, where the integrity of the self as a constituted meinber of the community is inost at stake. To paraphrase Rousseau, the lawyer must convince us that he is an orator, exercising his highest function as a citizen, when in reality he is simply a secret actor, "lost" in the identity of his chent.

This is extraordinarily disturbing. And so in popular culture we say of the lawyer, as the old adage goes, "A good lawyer must be a great har."35 Or we say, with Jonathan Swift, that lawyers are a "society of men . . . bred up from their youth in the art of proving by words inulti-

33. J. RoussEAU, supra note 32, at 79. In language that is often today applied directly to lawyers, Rousseau condemned the actor's profession as

a trade in which he performs for money, submits himself to the disgrace and the affronts that others buy the right to give him, and puts his person publicly on sale. I beg every sincere inan to tell if he does not feel in the depths of his soul that there is something servile Id. and base in this traffic of oneself.

Rousseau's complaint echoes earlier Puritan attacks on the acting profession, which were couched in specifically theological terms. Consider, for example, Wilham Prynne's diatribe against actors:

God requires truth in inward parts; in the soule, the affections; yea, in the habits, speeches, gestures, in the whole intire man. Now this counterfeiting of persons, affections, manners, vices, sexes, and the like, which is inseparably incident to the acting of Playes; as it transforms the Actors into what they are not; so it infuseth falshood into every part of soule and body, as all hypocrisie doth; in causing thein to seeme that in outward appearance which they are not in truth: therefore it must needs bee odious to the God of truth . . . .

W. PRYNNE, supra note 32, at 159.

34. J. RouSSEAU, supra note 32, at 80-81.

35. Dictionary of Proverbs, supra note 14 , at 139. 
plied for the purpose, that white is black and black is white, according as they are paid." 36

These hostile characterizations of the lawyer put her at a distance, as though her performances were something specially devious and different from the rest of us. If our acceptance of the acting profession demonstrates that we have come to acknowledge that role-playing is an integral aspect of modern experience, our excoriation of lawyers illustrates that this acceptance has definite limits. The performances of the lawyer are hidden, and hence they obliterate the distinction between the performing self and the true or innate self. But in this the lawyer is merely representative of the concealed performances we must all undertake every day. We would like to believe that we are the master of our many roles, rather than the reverse, but the persistent and unsettling example of the lawyer will not let us rest easy in this belief. If Goffman is correct, and if we are in fact constituted by our performances, the intensity of the animosity we bear toward lawyers may come precisely from the fact that they are so very threatening to our need to believe that we possess stable and coherent selves.

Analyzed in this way, the special hatred that popular culture holds for the lawyer can be an illuminating resource for understanding cultural contradictions of the deepest and most profound kind. The lawyer is the public and unavoidable embodiment of the tension we all experience between the desire for an einbracing and common community and the urge toward individual independence and self-assertion; between the need for a stable, coherent, and sincerely presented self and the fragmented and disassociated roles we are forced to play in the theater of modern life. In popular imagery the lawyer is held to strict account for the discrepancy between our aspirations and our realities. But this discrepancy is not the lawyer's alone, and once we understand this we may also come to see that in popular culture the lawyer is so much our enemy, because his failings are so much our own.

36. J. SWifT, Gulliver's Travels 295 (P. Dixon \& J. Chalker eds. 1967) (1726). 
